Research.

\title{
The effect of own capital rentability, solvability, profitability and liquidity on dividend policy in food and beverage sub sector companies listed on Indonesia Stock Exchange (IDX)
}

\author{
Wartoyo Hadi ${ }^{1^{*}}$, Nuraeni Rahayu ${ }^{2}$ \\ ${ }^{1 *}$ Department of Management, Economic College of Binaniaga, Bogor, Indonesia \\ ${ }^{2}$ Department of Management, Economic College of Binaniaga, Bogor, Indonesia \\ hadiwartoy009@gmail.com (W. Hadi), nuraenirahayu77@gmail.com (N. Rahayu) \\ "Corresponding author
}

Received: April 22, 2019; Accepted: May 28, 2019; Published: June 30, 2019

To cite this article: Hadi, Wartoyo, Nuraeni Rahayu. 2019. The effect of own capital rentability, solvability, profitability and liquidity on dividend policy in food and beverage sub sector companies listed on Indonesia Stock Exchange (IDX). The Management Journal of BINANIAGA. 4 (1): 37-50. doi:

\begin{abstract}
The aims of study to determine the effect of rentability of own capital, solvability, Profitability and Liquidity on dividend policy. The population of this study is all food and beverage sub-sector manufacturing companies listed on the Indonesia Stock Exchange (IDX) in 2015-2017 as many as 18 companies. While the sample is determined using the purposive sampling method. Companies that meet the criteria are only 7 companies. To analyze the data used multiple linear regression methods. The results of research, own capital rentability and current partial ratio (CR) has a negative and significant effect on the dividend payout ratio. Meanwhile, debt to equity ratio (DER) and return on assets (ROA) partially have a positive and significant effect on the dividend payout ratio. The results of the F-test show that the variable profitability of own capital rentability, solvency, profitability and liquidity simultaneously influence dividend policy.
\end{abstract}

Keywords: own capital rentability, debt to equity ratio, return on asset, current ratio, dividend payout ratio.

\section{Introduction}

The dividend is one of the important policies in the company because it involves shareholders, which incidentally are a source of capital from the company. Investors in investing their funds into stock instruments, of course, want a high return. Once the importance of the role of dividends, then the announcement of dividend payments by company management is a signal for investors. Management seems to indicate that the condition of the company is so strong that it can fulfill the payment of dividends to shareholders.

Dividend policy, in this case, uses the Dividend Payout Ratio ratio. Dividend Payout Ratio is the number of dividends the company gives to investors per shares sold. In this study, the variables used are the equity profitability, profitability, solvency and company liquidity. The first factor is Rentability of own capital is the ability of a company to earn profit from the total equity he owns. Company profits will become a reference in dividend payments. The second factor is solvency in this case with Debt to Equity Ratio (DER). The DER ratio is the ratio describes the company's ability to fulfill all its obligations indicated by several parts of its capital used to pay debts. This ratio also provides general

Wartoyo Hadi and Nuraeni Rahayu. The effect of own capital rentability, solvability, profitability and liquidity on dividend policy in food and beverage sub sector companies listed on Indonesia Stock Exchange (IDX) 
instructions about the company's financial feasibility and risk.

The third factor Profitability in this case ROA shows the ability of the company to make a profit or measure the effectiveness of the management of the company. This ratio looks at the extent to which the investment that has been invested can provide returns as expected. The fourth factor is liquidity is the ability of a company to fulfill its financial obligations which must immediately be fulfilled. Cash position or liquidity are the main considerations in many dividend policies. Because dividends for companies cash out, the greater the cash position and overall liquidity of the company will be the greater the company's ability to pay dividends. This ratio is also used to measure the level of security of a company. Manufacturing companies are companies with a group of issuers the largest listed on the IDX compared to other groups so the role is very dominant in the Indonesian economy. The 2015-2017 period recorded 18 sub-sector manufacturing companies food and drinks that are on Indonesia stock exchange. However, only seven companies distributed dividends for three consecutive years from 2015 to 2017. This research uses the food sub-sector manufacturing industry and drinks. Reason researched this company because it is one of the sectors interested in investors, this sector is one sector that can survive amid the economic conditions in Indonesia, besides that the prospects of the sector companies are very good because basically, every society needs food and drink in life. Based on this fact, food and beverage companies are considered to continue surviving.

However, it does not mean the food and beverage sector is a truly safe place for investors to invest their funds. The competitive business competition requires companies to be quick and precise in making strategic decisions. But this is not only true for companies, but an investor must also be able to make the right decision. The possibility of return and risk that will occur must be considered, meaning that there needs to be a measure that becomes the basis for an investor in making a decision. Based on these descriptions, researchers are interested in researching with the title "Effect of own capital, Solvability, Profitability, and liquidity on dividend policy in food and beverage sub-sector companies listed in The Indonesia Stock Exchange (IDX) Period 2015-2017.

\section{Literature Rreview and Hyphoteses}

\section{Dividend Policy}

According to Sudana, I.M (2011:167), revealed that dividend policy is related to determining the amount of payout dividends ratio, namely the magnitude of the percentage of profit clean after tax which is distributed as dividends to holders stock. According to Mustafa (2017:149) dividend policy is the profit obtained by the company distributed to shareholders as dividends and held in the form of retained earnings for future investment.

According to Atmaja (2008:286) dividend policy is related to the decision of whether the company will distribute dividends to shareholders or hold profits to be reinvested in profitable projects to increase the company's growth. From the above understanding, it can be concluded that dividend policy is a decision whether the profits obtained by the company at the end of the year will be shared with shareholders in the form of dividends or will be held to increase capital to finance investment in the future.

The dividend payout ratio according to Garrison et al (2014:32) is calculated using the formula:
DPR
$=\frac{\text { Dividends }}{\text { Net Income }}$
*) DPR = Dividend Payout Ratio

Wartoyo Hadi and Nuraeni Rahayu. The effect of own capital rentability, solvability, profitability and liquidity on dividend policy in food and beverage sub sector companies listed on Indonesia Stock Exchange (IDX) 


\section{Rentability}

According to Riyanto, B (2010:35), revealed that understanding of profitability is the ability of a company to generate profits during the period certain. According to Munawir (2010:33) that is to show the company's ability to generate profits for a certain period. While, according to Sudana, I.M. (2011: 22) profitability is the ability of a company to generate profits by using resources owned by the company, such as assets, capital or sales of the company. From the above definition, it can be concluded that the company's profitability can be known by comparing the profits obtained in a period with the number of assets or the amount of capital in the company.

The ratio of profitability according to Riyanto, B (2010: 36), namely:

a. Economic Rentability

The formula for economic rentability, according to Riyanto, B:

$$
\text { ER }
$$

EBIT X $100 \%$

Total Shareholders Equity

*) ER = Economic Rentability, EBIT: Earnings Before Interest and Taxes

b. Rentability of Own Capital

Understanding of own capital rentability according to Bambang Riyanto, B (2010:44) is a capability companies with their own capital working on it for make a profit. The rentability formula of own capital is as follows:

$$
\text { OCR }=\frac{\text { EAT } \times 100 \%}{\text { Own Capital }}
$$

*) OCR = Own Capital Rentability, EAT: Earnings After Taxes

3. Solvability

According to Prastowo, D (2014:89), revealed that solvency is the ability of a company to fulfill its long-term obligations. According to Kasmir (2017: 151) solvency is a ratio used to measure the extent to which a company's assets are financed by debt. According to Harahap (2015:303), revealed that solvency ratios describe the company's ability to pay its long-term obligations or obligations if the company is liquidated. From the above understanding it can be concluded that solvability shows the ability of a company to pay off all its existing debt using all of its assets. This study uses the Debt to Equity ratio (DER) as a solvability ratio because it is seen from the formula:

$$
\text { DER }=\frac{\text { EBIT } \times 100 \% \text { Total Liabilities }}{\text { Total Shareholders Equity }}
$$

*) DER = Deb to Equity Ratio

Reflecting the company's ability to fulfill all its obligations as indicated by some of its own capital used to pay off debt.

4. Profitability

According to Irham Fahmi (2014: 81), revealed that profitability is a ratio that measures management effectiveness the whole is indicated by large the small level of profit earned in relation to sales and investment. According to Mowen, et al. (2017:967) profitability is a ratio used to assess the extent to which company

Wartoyo Hadi and Nuraeni Rahayu. The effect of own capital rentability, solvability, profitability and liquidity on dividend policy in food and beverage sub sector companies listed on Indonesia Stock Exchange (IDX) 
resources are used efficiently. According to Brigham and Houston (2015:146) profitability is a group of ratios that show the combination and influence of liquidity, asset management and debt on operating results. From the definition above, it can be concluded that Profitability is the level of a company's ability to generate an income or income reflected in the company's profits, the management as the executor of a company has responsibility for the company's operations. This research uses return on assets $(\mathrm{ROA})$ as a profitability ratio because seen from the formula:

$$
\mathrm{ROA}=\frac{\text { Net Income }}{\text { Average total Assets }}
$$

\section{*) $\mathrm{ROA}=$ Retur On Assets}

This ratio can measure the ability of the company in generate profits from assets used. This ratio also looks at the extent to which the invested investment is able to provide returns as expected.

5. Liquidity

According to Brigham and Houston (2015:134), revealed that defining liquidity is a ratio that shows the relationship between cash and other company's current assets with its current liabilities. According to Mowen, et al. (2017:965) liquidity is the ratio used to assess a company's ability to pay its short-term debt.

According to Fahmi (2014:69), revealed taht liquidity is the ability of a company to fulfill term obligations in a timely manner. From the definition above, it can be concluded that liquidity is a ratio that is used to measure the ability of a company to meet obligations that are immediately due or current debts using current assets.

This study uses Current Ratio $(\mathrm{CR})$ as a liquidity ratio because it is seen from the formula:

$$
\mathrm{CR} \quad=\frac{\text { Current Assets }}{\text { Current Liabilities }}
$$

*) $\mathrm{CR}=$ Current Ratio

The formula is used to measure the level of security of a company (Cashmere: 134). This ratio also describes all current assets of the company.

Wartoyo Hadi and Nuraeni Rahayu. The effect of own capital rentability, solvability, profitability and liquidity on dividend policy in food and beverage sub sector companies 
6. Research Framework

The research framework can be described as the figure below:

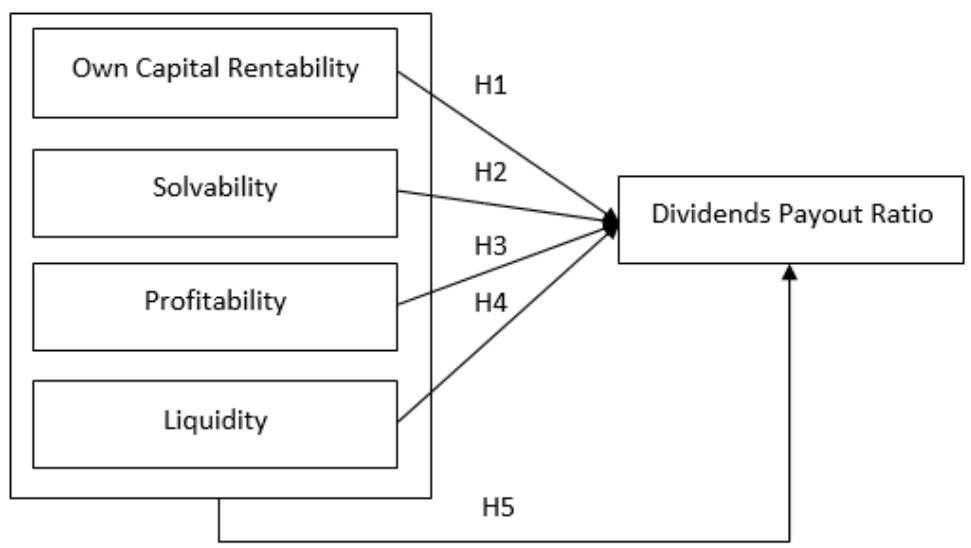

Figure 1. Research Framework

Based on the picture of the framework above, it can be explained that the independent variable in this study is the profitability of own capital, solvency, profitability and liquidity affecting the dependent variable, namely the Dividend Payout Ratio (DPR) either partially or simultaneously.

\section{Research Hypothesis}

Based on the frame of mind which has been described in the previous section then the hypothesis stated in this study is as follows:

H1: Own capital rentability influences to dividend policy

H2: Solvability influences to dividend policy

H3: Profitability influences to dividend policy

H4: Liquidity influences to dividend policy

H5: Own capital rentability, solvency, profitability and liquidity influence to dividend policy.

\section{Research Methodology}

1. Research Methods

The research method used is descriptive research. According to Etta (2010:21), namely research on problems in the form of current facts of a population which includes assessment activities, attitudes, or opinions of individuals, organizations, circumstances or procedures.

2. Population and Samples

The population used in this research is all food and beverage sub-sector companies listed on the Indonesia Stock Exchange (IDX) for the period 2015-2017. So that the total population is 18 companies. Sample selection is based on the Purposive method

Sampling, According to Sugiyono (2016: 85), purposive sampling is a sampling technique with consideration certain. The purpose of this method to get samples that fit the predetermined criteria. Because not all samples have criteria in accordance with what the researcher has determined Several criteria are set to obtain the following sample:

Wartoyo Hadi and Nuraeni Rahayu. The effect of own capital rentability, solvability, profitability and liquidity on dividend policy in food and beverage sub sector companies listed on Indonesia Stock Exchange (IDX) 
a. A sample company that has published financial statements for 3 (three) consecutive years, namely 2015 to 2017.

b. Sample companies that have data on dividend payments for three consecutive years during the study period of 2015 to 2017. Companies that do not pay dividends in a given year during the study period will be excluded from the sample. So, the number of samples obtained is 7 companies.

\section{Data Collection Method}

Data collection method done in this study is by literature study and documentation.

a. Literature study, which is done by reading books or journals in the library and the internet where there are references related to research.

b. Documentation, which is collecting, recording, and review documents about company financial data Food and Beverage sub-sector for the period 2015 2017 obtained from www.idx.co.id.

4. Types and Data Sources

The type of data used in this study is quantitative data taken based on reports Food and Beverage sub-sector companies listed on the Indonesia Stock Exchange (IDX) period 2015 - 2017 and the data sources used are secondary data obtained through www.idx.co.id

\section{Results and Discussion}

1. Descriptive Statistics

Table 1

Descriptive Statistics

Statistics

\begin{tabular}{|l|r|r|r|r|r|}
\hline & $\begin{array}{c}\text { Dividen } \\
\text { Payout Ratio }\end{array}$ & \multicolumn{1}{c|}{$\begin{array}{c}\text { Own Capital } \\
\text { Rentability }\end{array}$} & $\begin{array}{r}\text { Debt to Equity } \\
\text { Ratio }\end{array}$ & \multicolumn{1}{c|}{$\begin{array}{c}\text { Return On } \\
\text { Assets }\end{array}$} & Current Ratio \\
\hline Valid & 21 & 21 & 21 & 21 & 21 \\
Mean & 0 & 0 & 0 & 0 & 0 \\
Median & 49.8843 & 29.0633 & 93.9324 & 14.2381 & 2.6043 \\
Mode & 49.7000 & 19.6300 & 102.3700 & 10.9300 & 2.2500 \\
Std. Deviation & 100.00 & $4.80^{\mathrm{a}}$ & $17.14^{\mathrm{a}}$ & $2.97^{\mathrm{a}}$ & $.58^{\mathrm{a}}$ \\
Variance & 32.42286 & 33.20052 & 46.04222 & 12.80064 & 2.19648 \\
Range & 1051.242 & 1102.274 & 2119.886 & 163.856 & 4.825 \\
Minimum & 129.09 & 119.35 & 160.09 & 49.70 & 8.06 \\
Maximum & 16.67 & 4.80 & 17.14 & 2.97 & 58 \\
Sum & 145.76 & 124.15 & 177.23 & 52.67 & 8.64 \\
& 1047.57 & 610.33 & 1972.58 & 299.00 & 54.69 \\
\hline
\end{tabular}

a. Multiple modes exist. The smallest value is shown

Source: SPSS, data processed (2018)

Based on the results of data processing in table 6 it can be seen that $\mathrm{N}$ shows the amount of data processed, which is 21 data. dividend payout variable the ratio shows an average value of 49.88 , the middle value is 49.70 , the value that appears most often is 100 , the standard deviation is 32.42 , the diversity of data is 1051.24 , the data range is 129.09 , the lowest value is 16.67 , the highest value is 145,76 , and the total for the dividend payout ratio data is 1047.57.

The variable profitability of own capital shows an average value of 29.06 , the

Wartoyo Hadi and Nuraeni Rahayu. The effect of own capital rentability, solvability, profitability and liquidity on dividend policy in food and beverage sub sector companies 
middle value is 19.63 , the value the most frequently occurring is 4.80 , the standard deviation is 33.20 , data diversity of 1102.27 , the data range is 119.35 , the lowest value is 4.80 , the highest value is 124.15 , and the amount for the overall data on own capital profitability is 610.33 .

The variable debt to equity ratio which is a solvency ratio shows an average value of 93.93 , the middle value is 102.37 , the value most often appears as big as 17.14 , standard deviation of 46.04 , the diversity of data is 2119.89 , the data range is 160.09 , the lowest value is 17.14 , the highest value is 177.23 , and the total for the DER data is 1972.58 .

The variable return on assets which is the profitability ratio shows an average value of 14.24 , the middle value is 10.93 , the most frequently occurring value is 2.97 , the standard deviation is 12.80 , the diversity of data is 163.86 , the range data of 49.70 , the lowest value of 2.97 , the highest value of 52.67 , and the amount for the overall data ROA is 299.

The current ratio variable which is the liquidity ratio shows an average value of 2.60 , the middle value of 2,25 , the value that appears most often is 0.58 , the standard deviation is 2.19 , the diversity of data is equal to 4.83 , the data range is 8.06 , the lowest value is 0.58 , the highest value is 8.64 , and the total for CR data is 54.69 .

2. Normality Test

Table 2

Normality Test Results

One-Sample Kolmogorov-Smirnov Test

\begin{tabular}{|ll|r|}
\hline & & $\begin{array}{r}\text { Unstandardiz } \\
\text { ed Residual }\end{array}$ \\
\hline N & 21 \\
Normal Parameters & OE-b & Mean \\
& Std. Deviation & 21.52059051 \\
Most Extreme Differences & Absolute & 165 \\
& Positive & .165 \\
& Negative & -.135 \\
Kolmogorov-Smirnov Z & & .758 \\
Asymp. Sig. (2-tailed) & & .614 \\
\hline
\end{tabular}

a. Test distribution is Normal.

b. Calculated from data.

Source: SPSS, data processed (2018)

Based on the output in table 2 above, the sig value is obtained. equal to 0.614 greater than 0.05 , then the regression model in this case meets the assumption of normality, so the regression test can be continued.

Wartoyo Hadi and Nuraeni Rahayu. The effect of own capital rentability, solvability, profitability and liquidity on dividend policy in food and beverage sub sector companies listed on Indonesia Stock Exchange (IDX) 
The Management Journal of BINANIAGA Vol. 04, No. 01, June 2019 p-ISSN: 2527 - 4317, e-ISSN: $2580-149 x$

$6^{\text {th }}$ Accreditation Rating: April 04, 2019- April 03, 2024

3. Test of Classical Assumptions

a. Multicollinearity Test

Table 3

Multicollinearity Test Results

Coefficients $^{\mathrm{a}}$

\begin{tabular}{|ll|r|c|}
\hline \multirow{2}{*}{ Model } & \multicolumn{2}{|c|}{ Collinearity Statistics } \\
\cline { 3 - 4 } & & Tolerance & \multicolumn{1}{c|}{ VIF } \\
\hline 1 & Own Capital Rentability & .112 & 8.929 \\
& & & \\
& Debt to Equity Ratio & .207 & 4.830 \\
& Return On Assets & .141 & 7.085 \\
& Current Ratio & .261 & 3.828 \\
\hline
\end{tabular}

a. Dependent Variable: Dividen Payout Ratio

Source: SPPS, data processed (2018)

Based on the output in table 3 above, shows that the tolerance value of the independent variable own capital rentability by 0,11 ; DER of 0.20 ; ROA of 0.14 ; and CR is 0.26 greater than 0.1 and VIF value of Rentability of Own Capital is 8.9; DER of 4.8; ROA of 7.1; and CR of 3.8 is less than 10 , thus it can be concluded that multicollinearity does not occur, so a good and ideal regression model can be fulfilled.

b. Autocorrelation Test

Table 4

Autocorrelation Test Results

Model Summary ${ }^{\mathrm{b}}$

\begin{tabular}{|l|r|r|r|r|r|}
\hline Model & $R$ & R Square & $\begin{array}{c}\text { Adjusted R } \\
\text { Square }\end{array}$ & $\begin{array}{c}\text { Std. Error of } \\
\text { the Estimate }\end{array}$ & $\begin{array}{c}\text { Durbin- } \\
\text { Watson }\end{array}$ \\
\hline 1 & $.748^{\mathrm{a}}$ & .559 & .449 & 24.06075 & 1.766 \\
\hline
\end{tabular}

a. Predictors: (Constant), Current Ratio, Return On Assets, Debt to Equity Ratio, Own Capital Rentability

b. Dependent Variable: Dividen Payout Ratio

Source: SPSS, data processed (2018)

Based on the above output, it is known that the DW value is 1.766 , then we will compare this value with the significance table value of $5 \%$, the number of samples $N=21$ and the number of independent variables $4(K=4)$ then the du value is 1.69. The DW value of 1.766 is greater than du, which is 1.69 and less than (4-du) $4-1.69=2.31$. finished $1.69<1.766<2.31$. thus it can be concluded that there is no autocorrelation, so that a good and ideal regression model can be fulfilled.

Wartoyo Hadi and Nuraeni Rahayu. The effect of own capital rentability, solvability, profitability and liquidity on dividend policy in food and beverage sub sector companies listed on Indonesia Stock Exchange (IDX) 
c. Heteroscedasticity test

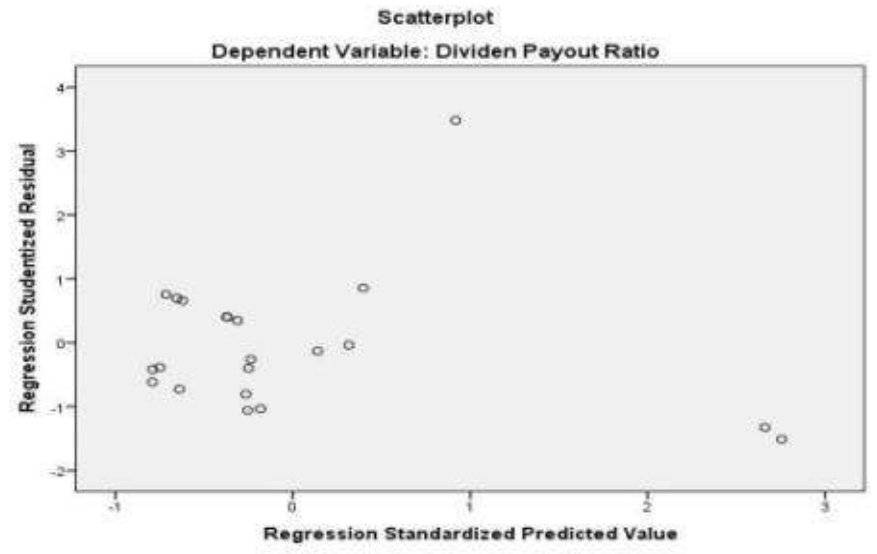

Source: SPSS, data processed (2018)

Figure 2. Heteroscedasticity Test Results

Based on the output above, it is known that data points spread above and below or around zero. The spread of data points does not form a wavy or narrow wavy pattern, thus it can be concluded that there is no problem of heteroscedasticity, so that a good and ideal regression model can be fulfilled.

4. Multiple Regression Analysis

Table 5

Multiple Regression Analysis

Coefficients $^{\text {a }}$

\begin{tabular}{|c|c|c|c|c|c|c|}
\hline \multirow{2}{*}{\multicolumn{2}{|c|}{ Model }} & \multicolumn{2}{|c|}{ Unstandardized Coefficients } & \multirow{2}{*}{$\begin{array}{c}\begin{array}{c}\text { Standardized } \\
\text { Coefficients }\end{array} \\
\text { Beta } \\
\end{array}$} & \multirow[b]{2}{*}{$t$} & \multirow[b]{2}{*}{ Sig. } \\
\hline & & $\mathrm{B}$ & Std. Error & & & \\
\hline \multirow[t]{5}{*}{1} & (Constant) & 149.918 & 60.084 & & 2.495 & .024 \\
\hline & Own Capital Rentability & -1558.950 & 510.368 & -17.313 & -3.055 & .008 \\
\hline & Debt to Equity Ratio & 3.334 & 1.091 & 4.734 & 3.057 & .008 \\
\hline & Return On Assets & 698.012 & 218.312 & 16.969 & 3.197 & .006 \\
\hline & Current Ratio & -12.883 & 5.029 & -.873 & -2.562 & .021 \\
\hline
\end{tabular}

a. Dependent Variable: Dividen Payout Ratio

Source: SPSS, data processed (2018)

Based on output in table 5 above, obtained multiple linear regression equations to determine the effect of rentability of own capital, solvency, profitability and liquidity on dividend policy as follows:

The constant value in the regression equation is 149,918 indicating that the dividend payout ratio ( $\mathrm{Y}$ ) value will be 149,198 if the profitability of equity (), DER (), ROA (), and CR () is zero. The regression coefficient value of self-equity profitability variable () of $-1558,950$ shows that dividend payout ratio will decrease by 1558,950 if the variable profitability of own capital increases by $1 \%$ while the variables DER, $\mathrm{ROA}$, and CR are constant. The negative sign indicates a unidirectional relationship between the equity profitability and the dividend payout ratio. Regression coefficient value of debt to equity ratio () of 3.334 shows that dividend payout ratio will increase by 3.334 if the debt to equity ratio increases by $1 \%$ while the variable Rentability of Own Capital, ROA, and CR are constant. A positive sign shows a unidirectional

Wartoyo Hadi and Nuraeni Rahayu. The effect of own capital rentability, solvability, profitability and liquidity on dividend policy in food and beverage sub sector companies listed on Indonesia Stock Exchange (IDX) 
relationship between the debt to equity ratio to the dividend payout ratio.

Regression coefficients variable return on assets () of 698,012 indicate that dividend payout ratio will increase by 698,012 if return on assets increases by $1 \%$ while the variable Remtability of Own Capital, DER, and CR is constant. A positive sign shows a unidirectional relationship between return on assets to dividend payout ratio.

The regression coefficient value of the current ratio () of $-12,883$ shows that the dividend payout ratio will decrease by 12,883 if the current ratio increases by $1 \%$ while the variable Rentability of Own Capital, DER, and ROA is constant. A negative sign indicates a unidirectional relationship between the current ratio and the dividend payout ratio.

5. Partial Test ( $\mathrm{t}$ test)

Table 6

Partial Test Results

Coefficients $^{a}$

\begin{tabular}{|c|c|c|c|c|c|c|}
\hline \multirow[b]{2}{*}{ Mode } & & \multicolumn{2}{|c|}{ Unstandardized Coefficients } & \multirow{2}{*}{$\begin{array}{c}\begin{array}{c}\text { Standardized } \\
\text { Coefficients }\end{array} \\
\text { Beta } \\
\end{array}$} & \multirow[b]{2}{*}{$t$} & \multirow[b]{2}{*}{ Sig. } \\
\hline & & B & Std. Error & & & \\
\hline \multirow[t]{5}{*}{1} & (Constant) & 149.918 & 60.084 & & 2.495 & .024 \\
\hline & Own Capital Rentability & -1558.950 & 510.368 & -17.313 & -3.055 & .008 \\
\hline & Debt to Equity Ratio & 3.334 & 1.091 & 4.734 & 3.057 & .008 \\
\hline & Return On Assets & 698.012 & 218.312 & 16.969 & 3.197 & .006 \\
\hline & Current Ratio & -12.883 & 5.029 & .873 & -2.562 & .021 \\
\hline
\end{tabular}

a. Dependent Variable: Dividen Payout Ratio

Source: SPSS, data processed (2018)

Based on output in table 6 above, shows the results of the statistical test $t$ between the independent variables on the dependent variable. Own capital rentability variable has a value of $t$ count of $-3,055$ with a significance level of 0,008 and $t$ table that has a value of 2,093 because the value of $t$ count $>t$ table $(3,055>$ 2,093 ) with significance $0,008<0,05$ can be concluded that $\mathrm{Ho}$ is rejected and $\mathrm{H} 1$ is accepted .

The debt to equity ratio variable has $t$ count of 3.057 with a significance level of 0.008 and $t$ table that has a value of 2.093 because the value of $t$ count $>t$ table (3.057 > 2.093) with a significance of $0.008<0.05$ can be concluded that Ho is rejected and $\mathrm{H} 2$ is accepted.

The return on assets variable has a value of $t$ count of 3.197 with a significance value of 0.006 and $t$ table which has a value of 2.093 because the value of $t$ count $>t$ table $(3.197>2.093)$ with a significance of $0.006<0.05$. The current ratio variable has a value of $t$ count of -2.562 with a significance value of 0.021 and $t$ table that has a value of 2.093 because the value of $t$ count $>t$ table $(2.562>2.093)$ with a significance of $0.021<0.05$.

Wartoyo Hadi and Nuraeni Rahayu. The effect of own capital rentability, solvability, profitability and liquidity on dividend policy in food and beverage sub sector companies 
6. Simultaneous Test (Test F)

Table 7

Simultaneous Test Results

ANOVA $^{\text {a }}$

\begin{tabular}{|ll|r|r|r|r|r|}
\hline Model & & \multicolumn{1}{c|}{$\begin{array}{c}\text { Sum of } \\
\text { Squares }\end{array}$} & \multicolumn{1}{c|}{ df } & Mean Square & F & Sig. \\
\hline 1 & Regression & 15425.657 & 4 & 3856.414 & 11.020 & $.000^{6}$ \\
& Residual & 5599.173 & 16 & 349.948 & & \\
& Total & 21024.831 & 20 & & & \\
\hline
\end{tabular}

a. Dependent Variable: Dividen Payout Ratio

b. Predictors: (Constant), Current Ratio, Own Capital Rentability, Debt to Equity Ratio, Return On Assets

Source: SPSS, data processed (2018)

Based on the output in table 12 above shows the calculated $F$ value of 11,020 with a significance level of 0,000 . Because the value of $F$ count $>F$ table $(11,020>$ 3,20 ) with a significance value of $0,000<0,05$, it can be concluded that rentability of equity, solvency (DER), profitability (ROA) and liquidity (CR) simultaneously influence policy dividends (DPR). The independent variable that has the most dominant influence on dividend policy is profitability (ROA).

7. Determination Coefficient Test

Table 8

Determination Coefficient Test Results

Model Summary

\begin{tabular}{|l|l|r|r|r|}
\hline Model & R & R Square & $\begin{array}{c}\text { Adjusted R } \\
\text { Square }\end{array}$ & $\begin{array}{c}\text { Std. Error of } \\
\text { the Estimate }\end{array}$ \\
\hline 1 & $.748^{\mathrm{a}}$ & .559 & .449 & 24.06075 \\
\hline
\end{tabular}

a. Predictors: (Constant), Current Ratio, Return On Assets, Debt to Equity Ratio, Rentabilitas Modal Sendiri

Source: SPSS, data processed (2018)

The adjusted $R$ square value of 0.449 means that $44.9 \%$ of the variation in dividend payout ratio can be explained by the four independent variables (Rentability of Own Capital, DER, ROA and CR) while $55.1 \%$ is explained by other factors that are not observed in research such as taxes, management attitudes, attitudes of lenders, market conditions, company internal conditions and financial flexibility.

8. Discussion

a. Effect of own capital rentability on dividend policy

The results of testing the first hypothesis using the $t$ test show that the variable own capital rentability has a negative and significant effect on dividend policy. This can be seen from the results of the average profitability of own capital in 2015 of 24.84, increasing in 2016 to 32.14 . While the average dividend payout ratio in 2015 of 51.08 decreased in 2016 to 47.50 . This is also supported by the condition of one food and beverage company, PT Multi Bintang Indonesia Tbk, in 2016 dividends decreased to 100\% from the previous year because the cost of goods increased by $21.14 \%$ from Rp. 592.21 billion to Rp. 488.86 billion while the profitability of own capital increased to $119.68 \%$

Wartoyo Hadi and Nuraeni Rahayu. The effect of own capital rentability, solvability, profitability and liquidity on dividend policy in food and beverage sub sector companies listed on Indonesia Stock Exchange (IDX) 
from the previous year by $64.83 \%$. In the $2015-2017$ period food and beverage companies focused more on infrastructure development such as building warehouses, purchasing fixed assets, repairing and adding factory buildings to support company productivity. The results of this study are in line with the results of the research conducted by Lievia Angela (2013). The results of this study are not in line with the results of the pious ahmadin research (2015).

b. Effect of solvability on dividend policy

The results of testing the second hypothesis using the t test show that the solvency variable (DER) has a positive and significant effect on dividend policy. The positive and significant effect of solvability (DER) means not in accordance with the theory put forward by cashmere (2017) that the lower the DER ratio indicates the better the company's performance because it causes higher returns and investors tend to choose low DER. During the 2015-2017 period the total debt of food and beverage companies experienced an increase due to the increase in current debt and long-term debt such as payment of maturing shortterm debt, bank debt for expansion and increase in post-employment benefit liabilities, but the increase in debt was still lower than total equity. The results of this study are in line with the results of Yudha's research (2017). the results of this study are not in line with the results of the study of budiman and harnovinsah (2016).

c. Effect of profitability on dividend policy

The third hypothesis testing results using the test show that the variable profitability (ROA) has a positive and significant effect on dividend policy. The influence of positive and significant profitability (ROA) means that this is in accordance with the theory of profitability and the results of ratio measurements ROA in seven food and beverage sub-sector companies, namely the higher return on assets, the greater the dividends to be paid. if the ROA ratio is low due to low profit margins due to low asset turnover.

During the 2015-2017 food and beverage companies experienced an increase in the number of current assets and fixed assets such as increases in capital expenditure, high accounts receivable, inventories and the amount of cash and cash equivalents from business revenue growth. The results of this study are in line with the results of research by Budiman and Harnovinsah (2016) and pious experts (2015). the results of this study are not in line with the results of aisyah (2017) research.

d. Effect of liquidity on dividend policy

The results of testing the fourth hypothesis using the $t$ test show that the variable liquidity $(\mathrm{CR})$ has a negative and significant effect on dividend policy. The influence of liquidity (CR) is negative and significant, this can be seen from the average current ratio in 2016 which increased by 267.52 compared to the previous year amounting to 237.86 while the average dividend in 2016 decreased by 47.50 from the previous 51.08 . This is because in the 2015-2017 period there was an increase in current liabilities, due to an increase in shortterm bank loans needed by the company for working capital for the current year. The increase in corporate debt can affect the company's liquidity, so the Company continues to maintain the level of liquidity, by paying attention to sound financial ratios, with the number of current assets and assets that exceed the amount of debt and current debt. The results of this study are in accordance with the results of aisyah and ayu (2017) and mufidah's research (2018). The results of this study are not in line with the results of the pious ahmadin research (2015).

Wartoyo Hadi and Nuraeni Rahayu. The effect of own capital rentability, solvability, profitability and liquidity on dividend policy in food and beverage sub sector companies listed on Indonesia Stock Exchange (IDX) 


\section{Conclusions and Suggestions}

1. Conclusion

Based on the results and discussion in this study, the researcher can conclude as follows:

a. Variable own capital rentability has a negative and significant effect on dividend policy.

b. Variability of solvability (DER) positive and significant effect on dividend policy.

c. Variable profitability (ROA) has a positive and significant effect on dividend policy.

d. Variable liquidity (CR) has a negative and significant effect on dividend policy.

e. Variable own capital rentability, solvency, profitability and liquidity together have a positive and significant effect on dividend policy.

\section{Suggestions}

a. Further research expanding the object of research, the number of samples and the period of the study year in order to produce better research than previous studies.

b. The researchers who want to examine dividend policy, it is better to add or replace independent variables in order to obtain different research results and the results can be more objective.

c. Investors by paying attention to variables that are significant to dividend policy, it is expected to know what aspects need to be considered when investing in the stock exchange.

\section{References}

Anwar, Y., Murwaningsari, E. (2017). The effect of credit risk and capital adequacy ratio upon return on asset (a case study at banking listed in Indonesia Stock Exchange). The Accounting Journal of Binaniaga, 02(02): 23-38.

Atmaja, L.S. (2008). Teori dan Praktik Manajemen Keuangan. Edisi 1. Yogyakarta: ANDI.

Atmoko, Y., Felisitas D., Irsan, T. (2017). Pengaruh return on assets, debt to equity ratio, dan firm size terhadap dividend payout ratio. Jurnal Ekonomi dan Manajemen, 14.

Brigham, E.F., Joel, F.H. (2015). Dasar-dasar Manajemen Keuangan. Buku 1. Jakarta: Salemba Empat.

Fahmi, I. (2014). Manajemen Keuangan Perusahaan dan Pasar Modal. Edisi Pertama. Jakarta: Mitra Wacana Media.

Garrison, R.H., Eric, W.N., Peter, C.B. (2014). Akuntansi Manajerial. Edisi $14 . \quad$ Jakarta: Salemba Empat.

Harahap, S.S. (2015). Analisis Kritis Atas Laporan Keuangan. Edisi Pertama. Jakarta: Rajawali Pers.

Herjanto, E. (2008). Manajemen Operasi. Edisi 3. Jakarta: Grasindo

Kasmir. (2017). Analisis Laporan Keuangan. Jakarta: Rajawali Pers.

Mowen, M.M., Don, R.H., Heitger, L. (2017). Dasar-Dasar Akuntansi Manajerial. Edisi 5. Jakarta: Salemba Empat.

Wartoyo Hadi and Nuraeni Rahayu. The effect of own capital rentability, solvability, profitability and liquidity on dividend policy in food and beverage sub sector companies listed on Indonesia Stock Exchange (IDX) 
The Management Journal of BINANIAGA Vol. 04, No. 01, June 2019

p-ISSN: 2527 - 4317, e-ISSN: $2580-149 x$

$6^{\text {th }}$ Accreditation Rating: April 04, 2019- April 03, 2024

Mufidah. (2018). Pengaruh Asset Growth, Sales Growth, Net Profit Margin, Current Ratio dan Debt To Equity Ratio terhadap Dividend Payout Ratio pada Perusahaan yang Termasuk dalam Indeks Lq 45 Tahun 2013-2016. Jurnal Manajemen dan Sains, 3(1).

Munawir, S. (2010). Analisa Laporan Keuangan. Yogyakarta: Liberty.

Musthafa. (2017). Manajemen Keuangan. Yogyakarta: ANDI.

Prastowo, D. (2014). Analisis Laporan Keuangan Konsep dan Aplikasi. Edisi Ketiga. Yogyakarta: STIM YKPN.

Riyanto, B. (2010). Dasar-Dasar Pembelanjaan Perusahaan. Edisi Empat. Yogyakarta: BPFE.

Sakti, J.A.W. (2017). Fakto yang Mempengaruhi Kebijakan Dividen Perusahaan yang Tergabung Dalam JII di BEI. Jurnal IImu Dan Riset Manajemen, 6(10).

Saleh, A. (2015). Pengaruh Rentabilitas Modal Sendiri, Solvabilitas, Profitabilitas dan Likuiditas Terhadap Kebijakan Deviden Pada Perusahaan Manufaktur yang Terdaftar di BEI Tahun 2011-2013. Jom FEKON, 2(1).

Sangadji, E. M., Sopiah. (2010). Metodologi Penelitian. Edisi 1. Yogyakarta: ANDI.

Sudana, I.M. (2011). Manajemen Keuangan Perusahaan Teori dan Praktik. Edisi 2. Jakarta: Erlangga.

Sugiyono. (2016). Metode Penelitian Kuantitatif, Kualitatif dan R\&D. Bandung: ALFABETA.

--------. (2010). Metode Penelitian Bisnis. Bandung: ALFABETA.

Umar, H. (2014). Metode Penelitian Untuk Skripsi Dan Tesis Bisnis. Edisi Kedua. Jakarta: Rajawali Pers.

www.idx.co.id

Wartoyo Hadi and Nuraeni Rahayu. The effect of own capital rentability, solvability, profitability and liquidity on dividend policy in food and beverage sub sector companies listed on Indonesia Stock Exchange (IDX) 